\title{
EVALUASI DAN PEMETAAN POTENSI DESA MITRA DPPM UII
}

\author{
Yulianto Purwono Prihatmaji*, Akhmad Fauzy**, Feris Firdaus***, M. Bambang Subekti*** \\ * Program Stusi Arsitektur FTSP Universitas Islam Indonesia \\ ** Program Studi Statistika FMIPA Universitas Islam Indonesia \\ *** Direktorat penelitian dan Pengabdian Masyarakat Universitas Islam Indonesia \\ Email: prihatmaji@yahoo.com
}

\begin{abstract}
Desa Mitra (Partners Village) DPPM UII is the embodiment of catur dharma UII, which is a program of community development and rural area development based on thematic local potential and sustainable. DesaMitra program has been done a long time, but intensively measured and planned starting in 2006. Collaborative research with the community, the diffusion of science and technology, community service is a program developed in the DesaMitra program supported from internal funds UII, external funds DIKTI and / or CSR from various companies. To measure the achievement of the objectives and benefits of the DesaMitra program is needed evaluation and mapping studies. Evaluation includes the fruit-fullness of the program, the community understanding and their awareness for self-sustained. Evaluation by purposive random sampling of the dozens DesaMitra acquired 7 villages, namely: Sendangagung, Sendangsari, Wukirsari, Sindumartani, Cokrodiningratan, which is located in the district of Sleman and Yogyakarta municipality. The results obtained 5 villages to be developed in near future considered their potential has not been developed, high motivation from community and supportsother related program. The 2 villages postponed to be developed assessed effectiveness of development assistance program and the level of self-developed of its people.
\end{abstract}

Keywords: evaluation, mapping, desamitra, mentoring, self-reliance

\section{PENDAHULUAN}

Desa mitra merupakan suatu program pembangunan masyarakat berupa penguatan kapasitas dan pembangunan sarana prasarana serta infrastruktur wilayah, dengan target lokasi desa yang memenuhi kriteria, potensi serta berminat untuk dikembangkan menjadi desa mitra DPPM UII. Program ini merupakan bentuk kepedulian terhadap keadaan dan kehidupan masyarakat di level desa yang sebenarnya memiliki berbagai potensi tetapi karena kurangnya sumber daya dan penguatan kapasitas, menyebabkan potensi tersebut tidak dapat dikelola dan dikembangkan dengan baik.

Selama ini program pembangunan di masyarakat lebih banyak direncanakan oleh lembaga penyelenggara program tanpa melibatkan warga secara langsung. Hal itu menyebabkan masyarakat tidak memiliki kepekaan terhadap program yang dilaksanakan, terkadang program yang diberikan juga tidak sesuai dengan apa yang menjadi kebutuhan masyarakat sehingga daya dukung masyarakat terhadap program tidak optimal dan efektif (Maksudin, 2001). 
Masyarakat memiliki harapan yang tinggi akan program dari lembaga-lembaga pengabdian masyarakat, artinya masyarakat masih memiliki ketergantungan tinggi terhadap keberadaan institusi ini. Paradigma ini harusnya dapat berubah, bahwa program pengabdian masyarakat bukan merupakan sarana untuk memberi, melainkan berusaha memberdayakan sumber daya alam dan sumber daya manusia yang ada sehingga tercipta masyarakat yang mandiri dan mampu mengembangkan potensinya sendiri. Masyarakat perlu dimotivasi untuk memberdayakan potensi ekonomi secara lokal.

Pada umumnya lokasi dan waktu pelaksanaan program tidak ditetapkan berdasarkan observasi, studi kelayakan atau evaluasi yang dilakukan oleh Tim pengabdian DPPM UII. Lokasi ditentukan berdasarkan kebutuhan atau permasalahan mitra yang diajukan ke DPPM UII. Hal tersebut diakibatkan karena kurangnya SDM pendukung yang mengerjakan pengabdian kepada masyarakat. Faktor lainnya adalah kelemahan sinergi antara bidang pengabdian dan bidang KKN yang belum memprioritaskan keberlanjutan program yang dilaksanakan pada masyarakat sehingga luaran program yang dicapai hanya bersifat temporary.

Observasi atau studi kelayakan sangat penting dilakukan, hal ini sebagai gambaran dalam mendampatkan potret desa/kelompok mitra tersebut layak untuk dijadikan khalayak sasaran atau lokasi mitra binaan. Menurut pendapat Mangkuprawiro (1993) bahwa untuk memilih dan menentukan permasalahan dalam masyarakat dilakukan analisis situasi yang mencakup analisis kebutuhan dan analisis potensi desa yang perlu untuk dipenuhi dan dibangun kembangkan.

Sehubungan dengan hal itu, Sukijo (2000) juga menyampaikan bahwa untuk memilih dan menentukan suatu desa bina/ desa mitra kerja sebelumnya perlu dilakukan studi kelayakan. Studi kelayakan itu pada dasarya juga untuk mengetahui potensi dan permasalahan yang terjadi dalam masyarakat. Lebih jauh lagi, hasil penelitian atau analisis kebutuhan atau analisis potensi yang telah diperoleh itu lebih baik kemudian diseminarkan, diusulkan, dan ditetapkan sebagai program institut. Selanjutnya, program itu dilaksanakan secara bertahap dan berkesinambungan dengan memperhatikan prinsip prioritas sesuai dengan urgensinya dalam masyarakat khalayak sasaran.

Disamping adanya studi kelayakan penetuan lokasi mitra sebaiknya ditentukan juga melalui pemetaan sosial masyarakat. Pemetaan sosial (social mapping) didefinisikan sebagai proses penggambaran masyarakat yang sistematik serta melibatkan pengumpulan data dan informasi mengenai masyarakat termasuk di dalamnya profile dan masalah sosial yang ada pada masyarakat tersebut (Maksudin, 2001). Merujuk pada Netting (1993), pemetaan sosial dapat disebut juga sebagai social profiling atau "pembuatan profile suatu masyarakat".

Secara umum tujuan pengabdian kepada masyarakat adalah memberikan kontribusi/membantu meningkatkan berbagai kebutuhan masyarakat serta memecahkan berbagai masalah yang dihadapi masyarakat agar kesejahteraan masyarakat menjadi rneningkat yang pada akhirnya masyarakat dapat hidup mandiri sejahtera dan baik. Menurut Slamet (1993) dikatakan bahwa tujuan pengabdian pada masyarakat oleh perguruan tinggi adalah :

a. Mempercepat proses peningkatan kemampuan sumberdaya manusia sesuai dengan dinarnika pembangunan;

b. Mempercepat upaya pengembangan masyarakat ke arah terbinanya masyarakat dinarnis yang siap mengikuti perubahan-perubahan ke arah perbaikan dan kemajuan yang sesuai dengan nilai-nilai rnasyarakat;

c. Mempercepat upaya pembinaan institusi dan profesi rnasyarakat sesuai dengan perkembangannya dalam proses modernisasi.;

d. Memperoleh umpan balik dan masukan lain bagi perguruan tinggi yang dapat dipergunakan untuk meningkatkan 
relevansi pendidikan dan penelitian yang dilakukannya dengan kebutuhan situasi,

Dari tujuan di atas dapat disimpulkan bahwa pengabdian kepada masyarakat oleh perguruan tinggi dapat diartikan sebagai praktek langsung dari teori yang diperoleh pada sebuah perguruan tinggi dari ilmu pengetahuan, teknologi, seni dan ilmu lainnya sesuai prosedur kaedah keilrnuan, dilakukan secara melernbaga, langsung kepada masyarakat sasaran (yang akan menikmatinya), dengan sasaran masyarakat baik perorangan, kelornpok, organisasi pemerintah/ swasta/masyarakat umum.

Proses pemilihan dan penetapan desa binaan yang dilakukan oleh Tim pengabdian DPPM Universitas Islam Indonesia belum melalui hal tersebut diatas sehingga untuk mengukur keberhasilan program, keberlanjutan atau perluasan lokasi mitra belum pernah dilakukan sampai saat ini dikarenakan ketiadaan penilaian atau evaluasi. Penilaian terhadap kondisi eksisting, yaitu antara lain efektivitas program bantuan yang telah dilakukan, kebutuhan masyarakat serta potensi dan masalah pengembangan di lapangan akan menjadi bahan untuk evaluasi. Evaluasi program bertujuan untuk menyediakan informasi serta rekomendasi bagi pengambil kebijakan (decission maker) untuk memutuskan apakah akan melanjutkan, memperbaiki atau tidak melanjutkan program binaan tersebut.

\section{Industri Kreatif Kerajinan Anyaman Bambu Dusun Brajan, Desa Sendangagung}

Dusun Brajan berada di wilayah Desa Sendangagung Kecamatan Minggir Kabupaten Sleman, Daerah Istimewa Yogyakarta. Lokasi Dusun Brajan ini berjarak + 20 km sebelah barat pusat Kota Yogyakarta, dimana berbatasan dengan Kabupaten Kulonprogo. Luas wilayah Dusun Brajan + 34 ha dan terdiri dari 3 Rukun Warga (RW) dan 6 Rukun Tetangga (RT). Jumlah penduduk dusun ini 663 jiwa yang tergabung dalam 185 Kepala Keluarga. Jumlah penduduk laki-laki adalah 348 jiwa dan perempuan adalah 315.
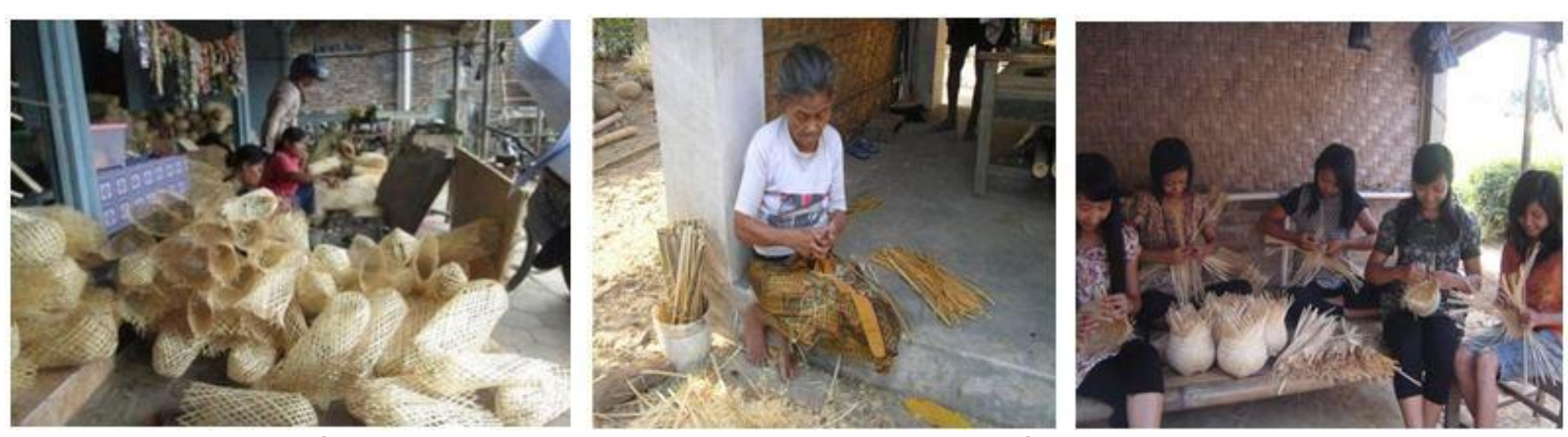

Gambar 1. Potensi kerajinan bambu di desa Sendangagung

Tampak dalam Gambar 1 bahwa kerajinan bambu menjadi icon dusun Brajan desa Sendangagung. Pada tahun 2005 Dusun Brajan ditetapkan sebagai desa wisata Kerajinan oleh Pemerintah Kabupaten Sleman. Ini didasarkan karena mayoritas penduduk di dusun ini berprofesi sebagai pengrajin bambu. Kemampuan kerajinan bambu adalah warisan dari nenek moyang penduduk dusun ini. Produksi kerajinan bambu di wilayah ini mulai berkembang pada tahun 1985.

\section{Industri Kreatif Anyaman Mendong, Dusun Plembon dan Parakan, Desa Sendangsari}

Kerajinan anyaman mendong di desa Sendangsari terdapat di pedukuhan Plembon dan pedukuhan Parakan Kulon. Awal mula adanya kerajinan diawali dari adanya pelatihan yang diadakan dari dinas perindustrian Kabupaten Sleman untuk 7 pelaku usaha yang dimagangkan ke Tasik Jawa Barat pada tahun 1997. Potensi bahan baku mendong yang dimiliki oleh kedua pedukuhan tersebut sangat besar mencapai $40 \mathrm{HA}$. 

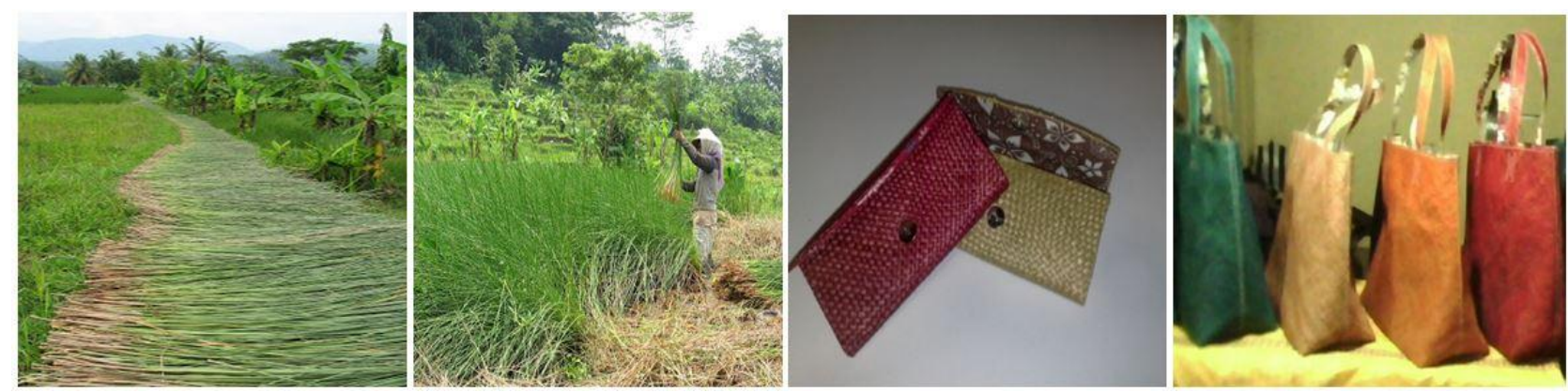

Gambar 2. Potensi bahan baku mendong dan produk turunannya desa Sendangsari

Tampak dalam Gambar 2 tersebut bahwa selain kerajinan bambu, terdapat potensi kerajinan mendong yang juga potensial untuk dikembangkan. Melimpahnya bahan baku mendong yang dimiliki tersebut tidak diimbangi dengan kesiapan SDM yang dimilki oleh kedua daerah tersebut, akibatnya hasil panen mendong $60 \%$ dijual ke daerah tasikmalaya Jawa Barat, $30 \%$ dijual untuk wilayah lokal dan hanya $10 \%$ yang dibuat anyaman kerajinan mendong. Adapun kerajinan yang dihasilkan oleh kedua daerah ini antara lain tikar, sajadah, dan kerai. Permasalahan tersebut yang melatar belakangi DPPM UII menjadikan Desa Sendangsari sebagai daerah mitra pada tahun 2010.

\section{UKM Pasir Semen Dusun Pusmalang, Desa Wukirsari}

Erupsi Gunung Merapi pada tahun 2010 membawa berkah tersendiri bagi masyarakat yang tidak mengalami musibah tersebut. Di karenakan Badan Geologi Kementerian ESDM memperkirakan terdapat lebih dari 140 juta meter kubik material pasir, kerikil, dan batu erupsi Merapi telah memenuhi sungaisungai yang berhulu di Gunung Merapi.

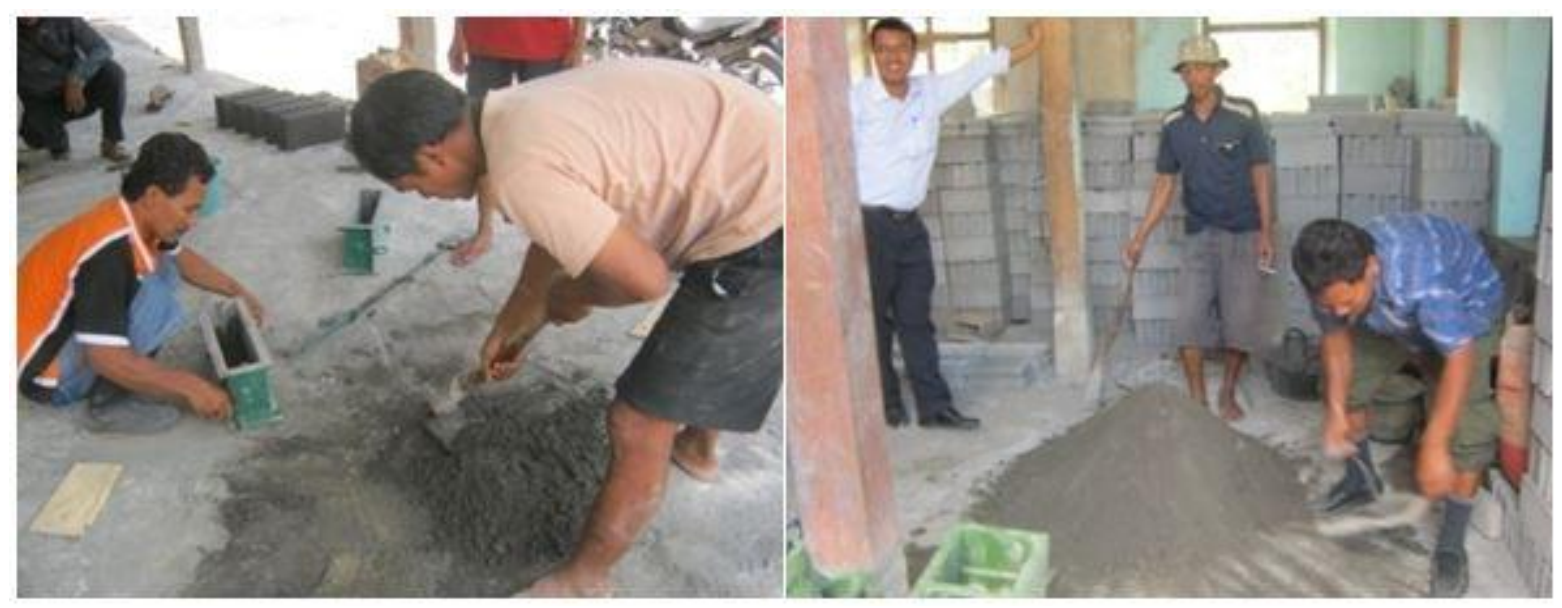

Gambar 3. Potensi produksi batako dan paving block dari pasir gunung Merapi

Tampak dalam Gambar 3 tersebut bahwa kelompok masyarakat telah melakukan produksi pembuatan batako dan paving blok dengan memanfaatkan limpahan pasir dari gunung merapi. Pemanfaatan pasir, kerikil, dan batu erupsi tersebut sangat baik digunakan sebagai bahan material pembangunan. Salah satu contoh pemanfaatan tersebut, dilakukan oleh kelompok masyarakat produktif "Mathuk" yang berlokasi di Dusun Pusmalang, Desa Wukirsari, Kecamatan Cangkringan Kabupaten Sleman Yogyakarta.

\section{Ekonomi Kreatif Berbasis Lingkungan di Dusun Morangan, Desa Sindumartani}

Dusun Morangan, dan Dusun Kalimanggis Desa Sindumartani, Kecamatan Ngemplak, Kabupaten Sleman secara geografis terletak di pinggir Kali Gendol. Sungai ini saat erupsi 
Merapi adalah sebagai salah satu jalan atau jalur bagi terjangan awan panas dan setelah erupsi menjadi jalan lahar dingin ketika hujan turun. Erupsi Gunung Merapi pada akhir tahun
2010 lalu telah membawa dampak luas terutama bagi masyarakat yang tinggal di lereng dan kaki Gunung Merapi.

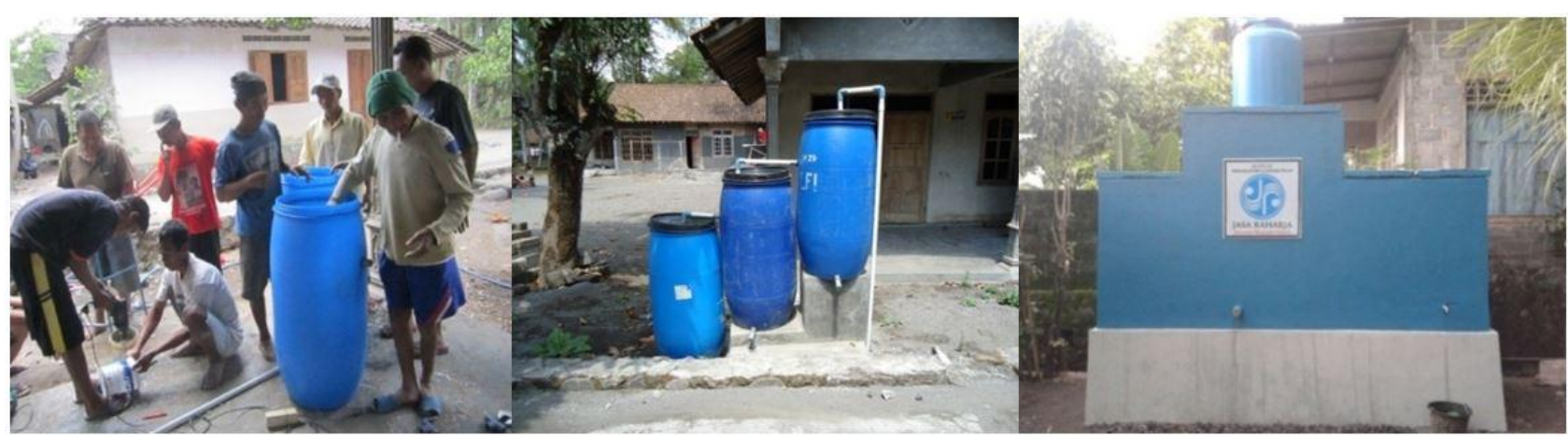

Gambar 4. Potensi sarana pemurnian air pasca erupsi gunung Merapi untuk penyediaan air bersih

Tampak dalam Gambar 4 tersebut bahwa masyarakat telah merancang alat penjernih air untuk penyediaan air bersih sehari-hari. Salah satu dampak pasca erupsi Merapi yang sampai saat ini masih dirasakan masyarakat adalah terjadinya kesulitan mendapatkan air bersih disaat musim kemarau. Sumber air baku penduduk Dusun Morangan sebelum terjadi erupsi Gunung Merapi mengandalkan air sumur gali. Pascaerupsi Gunung Merapi air yang mengalir di Kali Gendol kuning kecoklatan, demikian pula air sumur pinggir sungai tersebut termasuk di Dusun Morangan.

Air yang keruh dan kuning kecoklatan juga memberi dampak pada usaha ekonomi penduduk. Penduduk selama ini untuk mendapatkan air besih harus mengambil di tempat lain yang jaraknya 1 kilometer lebih. Penduduk di daerah ini mengalami kesulitan dalam dua aspek, yaitu aspek pengetahuan dan aspek pemberdayaan. Aspek pengetahuan terkait dengan kekurangtahuan penduduk cara perbaikan kualitas air dan atau sulitnya akses pengadaan alat pemulihan kualitas. Aspek pemberdayaan terkait lemahnya peran kelembagaan masyarakat dalam rangka mendapatkan solusi permasalahan kualitas air tersebut. Penduduk sebagian besar berpendidikan menengah ke bawah, yaitu rata-rata SMP. Penduduk hanya terkesan pasrah mendapatkan kenyataan kualitas air yang buruk. Penduduk juga sama sekali belum mengetahui bagaimana cara penjernihannya serta alat dan operasionalnya.

\section{Ekonomi Kreatif Berbasis Lingkungan dan Budaya Sungai Code, Kampung Jetisharjo, Kelurahan Cokrodiningratan}

RW 7 Kampung Jetisharjo, Kelurahan Cokrodingratan merupakan wilayah yang berada di sekitar bantaran Sungai Code. Seperti wilayah di bantaran sungai Code lainnya, RW 7 Kampung Jetisharjo mempunyai kualitas air yang buruk sebagai akibat dari pencemaran limbah baik industri, rumah tangga, dan perhotelan yang menempati sekitar bantaran Sungai Code. Dampak yang ditimbulkan dari pencemaran tersebut diantaranya dari segi kesehatan sangat berbahaya, karena air sungai masih dipergunakan untuk keperluan sehari-hari seperti mencuci, mandi atau pun air minum. Polusi air juga akan mengancam habitat ikan di sungai. Sungai yang tercemar dari segi estetika juga tidak nyaman, selain berwarna hitam, banyak sampah yang terapung dan baunya menyengat. 

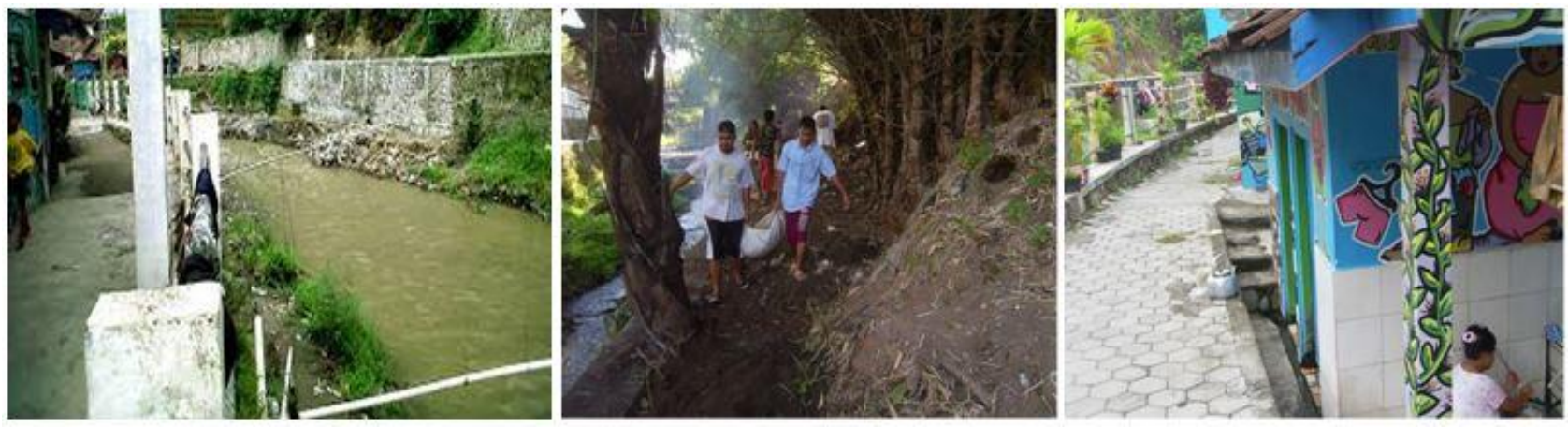

Gambar 5. Potensi ekonomi kreatif berbasis lingkungan sungai Code

Tampak dalam Gambar 5 tersebut bahwa sungai Code memiliki potensi lingkungan yang dap-at dikembangkan. Disamping persoalan tersebut diatas keberadaan hunian tempat tinggal permanen yang ada di sempadan Sungai Code yang diakibatkan dari tingkat pertumbuhan urbanisasi yang tidak terkontrol dengan baik menyebabkan fungsi lahan terbuka hijau di sepanjang di RW 7 saat ini hanya tinggal $\pm 5 \%$. Alih fungsi lahan tersebut diatas sebenarnya akibat dari lemahnya pengawasan pemerintah daerah dalam memberikan ijin hunian sementara bagi penduduk yang bertempat tinggal disepanjang sungai.Sebagai sungai yang membelah kota Yogyakarta menjadi dua bagian, keberadaan Sungai Code dapat menyebabkan bencana banjir diwilayah perkotaan.Bencana banjir tersebut dapat berasal dari lahar dingin akibat sisa erupsi Gunung Merapi pada tahun 2010 dan tingginya curah hujan yang melanda wilayah Yogyakarta. Rusaknya sumbersumber air dan sanitasi yang tertutup aliran lahan dingin Merapi pada tahun 2010 yang lalu menambah parahnya kerusakan lingkungan Sungai Code saat ini.

\section{METODE PENELITIAN}

Penelitian ini adalah penelitian lapangan, yaitu suatu penelitian yang dilaksanakan secara intensif dan terperinci terhadap suatu objek yang diinginkan dengan mempelajari berbagai data penguat atau pendukung suatu kasus (Nawawi 1995). Penelitian ini dilakukan dengan cara terjun langsung di Desa Brajan Desa Sendangagung, Desa Plumbon dan Parakan kulon Desa Sendangsari, Desa Pusmalang Desa Cangkringan, Desa Morangan Desa Sindumartani Ngemplak
Sleman, Kampung Cokrodiningratan Desa Jetisharjo yang dijadikan objek penelitian, sehingga data pokok yang dibutuhkan dalam penelitian dapat diperoleh. Penelitian yang dimaksudkan untuk suatu fakta temuan di lapangan, menggunakan penelitian dsekripsi, yaitu untuk pengukuran yang cermat terhadap fenomena sosial tertentu (Singarimbun 1995).

Penelitian menggunakan teknik analisis deskriptif, yaitu statistika yang mempelajari cara pengumpulan data dan penyajian data sehingga mudah dipahami. Statistika deskriptif hanya berhubungan dengan hal menguraikan atau memberikan keteranganketerangan mengenai suatu data atau keadaan. Statistika deskriptif berfungsi menerangkan keadaan, gejala, dan persoalan, sedangkan penarikan kesimpulan pada statistika deskriptif hanya ditunjukkan pada kumpulan data yang ada (Hasan, 2001). Statistika deskriptif merupakan bagian statistika mengenai pengumpulan data, penyajian, penentuan nilai-nilai statistika, pembuatan diagram atau gambar mengenai sesuatu hal, disini data yang disajikan dalam bentuk yang lebih mudah dipahami dan dibaca (Subagyo, 2003).

Wilayah penelitian ini dilaksanakan di Desa Brajan Desa Sendangagung, Desa Plumbon dan Parakan kulon Desa Sendangsari, Desa Pusmalang Desa Cangkringan, Desa Morangan Desa Sindumartani Ngemplak Sleman, Kampung Cokrodiningratan Desa Jetisharjo. Penelitian awal dilakukan dengan metode deskriptif evaluatif, merupakan metode yang mencoba menggambarkan pelaksanaan program.

Analisis data menggunakan metode kualitatif. Analisis data dilakukan terhadap 
data primer maupun data sekunder dengan menggunakan parameter tertentu. Sampel yang digunakan dalam penelitian ini bersumber dari key person yang sangat mengetahui proses pelaksanaan program dengan wawancara secara mendalam (Maksudin, 2001).

\section{HASIL DAN PEMBAHASAN}

\section{Industri Kreatif Kerajinan Anyaman Bambu Desa Brajan, Desa Sendangagung}

Desa Brajan, Desa Sendangagung sebagai desa mitra DPPM UII dengan potensi produk anyaman bambu dan telah dilakukan pendampingan selama 8 (delapan) tahun mulai dari tahun 2007 sampai dengan 2014, dengan melihat parameter keberhasilan dan indikator yang telah ditentukan didapat hasil observasi sebagai berikut:

\section{A. Keberhasilan Program}

Kesejahteraan masyarakat semakin meningkat, karena masyarakat dapat mengembangkan usaha kerajinannya menjadi lebih kreatif sehingga nilai ekonomis semakin tinggi. Tingkat kesejahteraan yang meningkat juga terlihat dari berkurangnya pengangguran di usia produktif, dengan menjadikan usaha kerajinan sebagai pekerjaan utamanya. Program peningkatan SDM dalam pemasaran dan networking berjalan lancar, penambahan jaringan pemasaran secara online dijalankan dengan baik oleh pengelola dan berguna bagi peningkatan penjualan, dimana pengunjung dapat mengakses website www.bambubrajan.com, dan dapat melihat produk yang diproduksi,serta melakukan pembelian secara online. Pelatihan komunikasi akan meningkatkan kemampuan berkomunikasi dan bernegosiasi dengan calon buyer, khususnya buyer dari luar negeri. Bertambahnya jaringan pemasaran dan kemampuan komunikasi dengan buyer meningkatkan daya jual masyarakat.Jenis produk yang semakin beragam sesuai perkembangan zaman sehingga bisa memenuhi permintaan konsumen.

\section{B. Pemahaman Masyarakat Terhadap Program}

Program DPPM UII direncanakan dan diselenggarakan sesuai dengan kebutuhan masyarakat. Masyarakat dilibatkan mulai proses pemetaan potensi dan permasalahan hingga terealisasinya program tersebut. Dari data yang diperoleh, keterlibatan masyarakat pada inisiasi program ataupun pelatihan cukup tinggi, mulai dari pengrajin, perangkat desa, generasi muda dan ibu-ibu. Kelembagaan kerajinan bambu sudah berjalan dengan baik, antara lain koperasi kerajinan bambu, dimana tujuan koperasi ini adalah membantu membangun kesejahteraan masyarakat dengan program kegiatannya seperti simpan pinjam dan membantu modal usaha kerajinan. Dengan adanya potensi yang ada, banyak instansi pemerintah maupun swasta yang menawarkan program demi terwujudnya sebuah kawasan yang mandiri.

\section{Kesadaran Masyarakat Untuk Mandiri}

Masyarakat Desa Brajan sudah terbiasa sejak dulu hidup bergotong royong, mereka berswadaya untuk membangun jalan-jalan lingkungan agar dapat meningkatkan aktivitas masyarakat. Desa Brajan memang masih menjadi pusat kerajinan bambu sampai sekarang karena dilihat dari permintaan pasar memang lebih berminat untuk membeli hasil produksi kerajinan bambu dari desa ini. Melihat peningkatan yang ada di Desa Brajan, desa-desa disekitarnya juga mengikutinya untuk membuka usaha kerajinan bambu. Program selanjutnya yang ingin dikembangkan berupa perencanaan penataan kawasan yang terpadu misalnya semacam pasar terpadu untuk menjual hasil produksi sehingga aktifitas jual beli tidak hanya dilakukan dirumah-rumah pengrajin. Masalah yang harus diwaspadai adalah ketika tawaran bantuan yang terus berdatangan akan mengurangi sikap etos kerja mereka dan warga akan terus berharap mendapatkan program bantuan.

Program kegiatan di Desa Sendangagung masih terpusat di desa Brajan, sehingga Desa Brajan terlihat lebih maju dibanding desa 
tetangganya. Sesungguhnya masih banyak potensi desa yang belum digali dengan maksimal, berbagai potensi Desa Sendangagung antara lain:

a. Memiliki peruntukkan ruang sebagai kawasan industri rumah tangga

b. Salah satu desa mandiri pangan di Kabupaten Sleman

c. Memiliki produk perencanaan

d. Konsep dan manajemen produk sudah berjalan

e. Lingkungan masyarakat sebagai pelaku industri

Industri kreatif kerajinan anyaman bambu Desa Brajan, Desa Sendangagung dari hasil pembahasan terkait parameter dan indikator, didapatkan bahwa keberhasilan program sangat ditentukan oleh pengembangan embrio potensi desa yang memiliki daya ungkit kuat untuk pengembangan dan keberlanjutan program. Selain itu kesiapan masyarakat dan kelembagaan yang kuat juga berpengaruh terhadap kesinambungan program untuk desa mitra binaan DPPM UII.

\section{Industri Kreatif Anyaman Mendong, Desa Plembon dan Parakan, Desa Sendangsari}

Desa Plembon dan Desa Parakan, Desa Sendangsari sebagai desa mitra DPPM UII dengan potensi industri kreatif anyaman mendong, telah mendapatkan pendampingan selama 5 (lima) tahun mulai dari tahun 2010 sampai dengan 2014, dengan melihat parameter keberhasilan dan indikator yang telah ditentukan didapat hasil observasi sebagai berikut:

\section{A. Tingkat Keberhasilan Program}

Desa Plembon dan Desa Parakan, Desa Sendangsari memiliki potensi yang serupa dengan desa tetangganya, desa sendang agung, yaitu kerajinan. Bila Sendag Agung merupakan sentra kerajinan bambu, maka desa sendang sari adalah penghasil mendong. Berbagai program bantuan telah dilaksanakan DPPM UII yang bertujuan untuk meningkatkan wirausaha dan kesejahteraan masyarakat. Respon dari masyarakat pada saat itu positif, baik dari masyarakat, pengrajin, serta aparat desa. Program kegiatan yang diadakan DPPM UII dapat dengan mudah dipelajari dan ditiru. Bantuan teknologi pengering mendong sangat membantu masyarakat dalam kegiatan wirausahanya, terutama mereka terbantukan dari sisi waktu.

Tanaman mendong yang berlimpah ruah tadinya hanya dijual ke beberapa daerah seperti Tasikmalaya dan dengan harga yang murah. Dengan adanya program pelatihan membuat produk anyaman dari DPPM UII, masyarakat telah memberikan nilai tambah pada tanaman mendong menjadi suatu kerajinan, yang bila dijual, tentu nilainya lebih tinggi. Program DPPM UII tersebut dilaksanakan pada tahun 2010, dan belum ada keberlanjutannya lagi.

\section{B. Pemahaman Masyarakat Terhadap Program}

SDM yang ada di desa Plembon dan Parakan dirasa sangat kurang. Ketika DPPM UII masuk ke desa, masyarakat antusias dengan program kegiatan tersebut. Kurangnya pengetahuan dan ketrampilan warga menjadi dasar DPPM UII melakukan pelatihan menganyam. Masyarakat terlibat dari awal dilakukan pemetaan potensi, FGD yang dihadiri dari berbagai kalangan warga, baik pengrajin dan perangkat desa hingga terlaksananya pendampingan dan pelatihan.

\section{Kesadaran Masyarakat untuk Mandiri}

Sebagian masyarakat belum dapat meneruskan program yang ada terkait kerajinan mendong, mereka lebih senang dengan menjual bahan baku mendong secara mentah karena banyak permintaan dari berbagai daerah. Keinginan untuk menciptakan daya saing masih terbilang kurang. Penyebabnya antara lain sdm yang kurang, dan kurangnya diversifikasi produk yang menyebabkan kurangnya permintaan pasar. Jumlah pengrajin masih sedikit sehingga belum bisa memberikan hasil yang maksimal. Generasi muda cenderung untuk bekerja di kota dan tidak meneruskan usaha orang tua. Akses untuk memperoleh jaringan 
atau koneksi minim salah satunya adalah disebabkan oleh kurangnya akses teknologi.

Potensi terbesar dari Desa Sendangsari adalah tanaman mendong yang melimpah. Potensi tersebut belum dimaksimalkan pengelolaannya oleh penduduk, dikarenakan kemampuan SDM dalam mengolah masih kurang, sehingga membutuhkan pelatihan SDM sebagai pelaku industri. Regenerasi pelaku industri untuk keberlanjutan program perlu di kembangkan seiring dengan mindset para pemuda yang merasa lebih gagah bila bekerja di perkotaan.

Industri kreatif kerajinan anyaman mendong Desa Plembon dan Parakan, Desa Sendangsari dari hasil pembahasan terkait parameter dan indikator, didapatkan bahwa program yang dilaksanakan belum dapat memaksimalkan potensi yang ada, DPPM UII hendaknya dapat melakukan dukungan penguatan kapasitas masyarakat terutama bagi para pelaku industri. Perlunya sosialisasi secara bertahap kepada masyarakat sebagai upaya untuk melakukan regenerasi agar generasi muda sebagai penggerak aktivitas masyarakat merasa memiliki dan bertanggung jawab untuk keberlanjutan program bagi wilayahnya.

\section{UKM Pasir Semen Desa Pusmalang, Desa Wukirsari}

Desa Pusmalang, Desa Wukirsari sebagai desa mitra DPPM UII dengan potensi pengola, telah mendapatkan penhan pasir dampingan selama 2 (dua) tahun mulai dari tahun 2012 sampai dengan 2013, dengan melihat parameter keberhasilan dan indikator yang telah ditentukan didapat hasil observasi sebagai berikut:

A. Keberhasilan Program,

Dampak dari program ini pada awalnya memang sangat baik, penghasilan masyarakat meningkat karena permintaan atau hasil penjualannya baik. Program ini memang masih berjalan tetapi tidak seperti awalnya, karena jumlah tenaga kerjanya semakin berkurang. Tujuan dari program ini adalah untuk meningkatkan kualitas SDM, ekonomi atau pendapatan masyarakat, sehingga dapat memanfaatkan sumber daya alam yang ada untuk meningkatkan kehidupan ekonominya untuk mencapai suatu kehidupan masyarakat yang sejahtera.

Pada awalnya tujuan dari program ini salah satuhnya adalah untuk mengurangi jumlah pengangguran, namun dalam kenyataannya sekarang tingkat pengangguran tetap tidak berkurang karena memang masyarakat yang pada awalnya sudah bekerja sebagai tukang batu atau yang aktif dalam program ini sekarang banyak yang beralih ke pekerjaan yang lain seperti buru tani, ataupun karyawan swasta (buruh pabrik).

\section{B. Pemahaman Masyarakat Terhadap Program \\ Perkembangan pembangunan saat ini} berkembang sangat meningkat, ini mempengaruhi permintaan akan kebutuhan batuan seperti bata atau batako. Jika program ini terus dikembangkan sesuai dengan kebutuhan permintaan yang ada sekarang, maka akan sangat bermanfaat bagi masyarakat Desa Pusmalang, perekonomian masyarakat dapat meningkat karena tingginya permintaan akan bahan bangunan. Program ini sebenarnya sangat membantu meningkatkan kehidupan perekonomian masyarakat jika terus dilaksanakan namun perlu adanya pendampingan dan pelatihan manajemen yang baik agar hasil produksi dapat bersaing di pasaran.

Masyarakat tidak kondusif untuk terus mengembangkan program ini karena dapat dilihat dari pekerja yang awalnya aktif dalam program ini semakin berkurang dan beralih ke pekerjaan lain. Masyarakat Desa Pusmalang pada umumnya bekerja sebagai petani, buruh tani, karyawan swasta (buruh pabrik), dan perikanan air tawar, jumlah permintaan akan hasil produksi juga semakin berkurang. Pada awalnya tenaga kerja yang aktif sekitar 20-30 orang namun sekarang yang aktif hanya 1015 orang. Tenaga kerja yang dulunya aktif sekarang banyak yang beralih ke pekerjaan lain seperti buruh tani, tukang batu. Meskipun mempunyai lembaga sendiri yang mengurusi program ini, tetapi karena keterbatasan sumber daya dan permintaan, maka program 
ini dilaksanakan ketika ada permintaan bahan bangunan.

\section{Kesadaran Masyarakat untuk Mandiri}

Sebelum adanya erupsi Merapi, masyarakat telah terbiasa gotong royong, terlebih setelah adanya erupsi, masyarakat dengan berswadaya saling membantu memperbaiki rumah. Dengan adanya bantuan DPPM UII masyarakat dengan semangat membuat produk salah satunya sebagai bahan untuk memperbaiki rumah mereka yang rusak. Keterbatasan SDM dan saat ini dengan meningkatnya harga bahan baku, masyarakat beralih ke mata pencahariaan sebelumnya, yaitu antara lain peternakan dan perikanan. Keterbatasan SDM ini juga yang membatasi mereka akan pengembangan jaringan dan mitra.

Progam DPPM UII di Desa Wukirsari tepatnya di Desa Pusmalang diawali dengan adanya bencana erupsi merapi yang ternyata tidak hanya menimbulkan kerusakan, tetapi juga memberikan sesuatu yang dapat dimanfaatkan masyarakat, yaitu pasir dari erupsi yang melimpah ruah. Program yang dilaksanakan DPPM UII antara lain pembuatan batako tidak lama beroperasi. Kurangnya kualitas barang menyebabkan permintaan berkurang, sehingga warga kembali pada pekerjaan semula, yaitu antara lain, bertani dan beternak, serta menjadi buruh. Selain bahan baku pasir, Desa Wukirsari memiliki berbagai potensi, antara lain:

a. Tersedianya sumber daya manusia untuk mengolah bahan baku

b. Adanya teknologi yang masuk ke desa wukirsari

c. Potensi perikanan

d. Sumber mata air

UKM pasir semen Desa Pusmalang, Desa Wukirsari dari hasil pembahasan terkait parameter dan indikator, didapatkan bahwa program yang dilaksanakan pada saat itu sangat tergantung dengan kondisi alam sebagai dampak dari erupsi Gunung Merapi. Potensi ini dapat optimal pengembangan dan diversifikasi produknya apabila masyarakat secara mandiri mampu memperbesar jaringan pemasaran dengan manajemen pengelolaan yang baik.

\section{Ekonomi Kreatif Berbasis Lingkungan di Desa Morangan, Desa Sindumartani}

Desa Morangan, Desa Sindumartani sebagai desa mitra DPPM UII dengan potensi pengelola, telah mendapatkan dampingan pada tahun 2012 setelah terjadinya erupsi Gunung Merapi, dengan melihat parameter keberhasilan dan indikator yang telah ditentukan didapat hasil observasi sebagai berikut:

\section{A. Keberhasilan Program,}

Program yang telah dilakukan oleh DPPM UII yaitu pembuatan water treatment air bersih. Dampak/ hasil dari pendampingan program UII dirasakan sangat positif oleh Masyarakat setempat karena dapat memenuhi kebutuhan air bersih dari Masyarakat di Desa Morangan. Tujuan dari program yang telah dilakukan yaitu tersedianya air bersih sudah tercapai ditinjau dari segi pemenuhan kebutuhan masyarakat akan air bersih. Dengan adanya program pengelolaan air bersih yang telah dilakukan, maka perekonomian masyarakat di Desa Morangan mengalami peningkatan karena masyarakat tidak perlu mengeluarkan biaya untuk memperoleh air bersih. Program yang akan dilakukan selanjutnya yaitu mengembangkan program yang sudah ada, agar kedepannya kebutuhan akan air bersih dari masyarakat dapat terpenuhi demi kesejahteraan masyarakat Desa Morangan.

\section{B. Pemahaman Masyarakat Terhadap Program \\ Berkaitan dengan program yang telah} dilakukan, maka masyarakat merespon dengan positif untuk melakukan perubahan ke arah perkembangan pengelolaan air bersih yang nantinya berimplikasi pada peningkatan taraf hidup/ tingkat kesejahteraan masyarakat. Berdasarkan hasil survey yang dilakukan di Desa Morangan, maka program pendampingan yang dilakukan oleh DPPM UII 
sangat membantu karena dapat memenuhi kebutuhan air bersih dari masyarakat setempat. Dari perspektif/ sudut pandang bidang perencanaan, tersedianya jaringan air bersih yang termasuk dalam kategori utilitas umum sangat membantu dalam penentuan tingkat kesejahteraan masyarakat. Oleh karena itu, diperlukan daya dan upaya dari masyarakat untuk dapat mengembangkan program yang sudah ada agar kedepannya dapat memenuhi kebutuhan air bersih dari masyarakat di Desa Morangan. Pengelolaan alat water treatment dilakukan dengan baik oleh pengelola dan warga sendiri. Perawatan dilakukan secara berkala dengan menggunakan uang iuran warga.

\section{Kesadaran Masyarakat Untuk Mandiri}

Kesadaran warga untuk memperoleh air bersih membuat mereka konsisten dalam mengelola program ini. Sikap gotong royong pun tercermin dari swadaya masyarakat dengan rela membayar uang iuran $R p$ 500/bulan untuk perawatan alat bantuan tersebut. Saat ini warga sedang merencanakan untuk kegiatan selanjutnya, yaitu pembuatan sumur sebagai lahan perikanan dan untuk meningkatkan debit air, yang kemudian akan diajukan ke mitra.

Program DPPM UII tidak saja hanya melihat pada potensi yang ada, tetapi juga melihat permasalahan yang ada. Sesuai dengan permasalahan di Desa Sindumartani yaitu kurangnya pasokan air bersih setelah terjadinya erupsi Gunung Merapi, DPPM UII memberikan bantuan berupa water treatment system, dengan tujuan memberikan pasokan air bersih bagi warga. Program tersebut berjalan sesuai dengan tujuan, warga terpenuhi akan kebutuhan air bersih. Pengelolaan pun masih berjalan hingga kini.

Satu permasalahaan yakni air bersih sudah dapat teratasi, saatnya melihat potensi yang ada di Desa Sindumartani untuk dapat digunakan dengan maksimal, antara lain :
a. Memiliki produk perencanaan
b. Potensi perikanan
c. Masyarakat kondusif untuk pembangunan

d. Daerah yang berbatasan dengan Klaten ( salah satu pintu masuk dari Jawa tengah )

Industri kreatif kerajinan anyaman mendong Desa Plembon dan Parakan, Desa Sendangsari dari hasil pembahasan terkait parameter dan indikator, didapatkan bahwa program yang dilaksanakan belum dapat memaksimalkan potensi yang ada, DPPM UII hendaknya dapat melakukan dukungan penguatan kapasitas masyarakat terutama bagi para pelaku industri. Perlunya sosialisasi secara bertahap kepada masyarakat sebagai upaya untuk melakukan regenerasi agar generasi muda sebagai penggerak aktivitas masyarakat merasa memiliki dan bertanggung jawab untuk keberlanjutan program bagi wilayahnya.

\section{Ekonomi Kreatif Berbasis Lingkungan dan Budaya Sungai Code, Kampung Jetisharjo, Kelurahan Cokrodiningratan}

Seperti wilayah di bantaran sungai Code lainnya, RW 7 kecamatan Jetisharjo mempunyai kualitas air yang buruk sebagai akibat dari pencemaran limbah baik industri, rumah tangga, dan perhotelan yang menempati sekitar bantaran Sungai Code. Dampak yang ditimbulkan dari pencemaran tersebut diantaranya dari segi kesehatan sangat berbahaya, karena air sungai masih dipergunakan untuk keperluan sehari-hari seperti mencuci, mandi atau pun air minum. Polusi air juga akan mengancam habitat ikan di sungai. Sungai yang tercemar dari segi estetika juga tidak nyaman, selain berwarna hitam, banyak sampah yang terapung dan baunya menyengat, dengan melihat parameter keberhasilan dan indikator yang telah ditentukan didapat hasil observasi sebagai berikut:

\section{A. Keberhasilan Program}

Program dari DPPM UII bertemakan EcoSpiritual, dimana masyarakat didorong secara spiritual untuk mendorong partisipasinya dalam mengelola Kawasan Code. Kegiatan dilakukan melalui penyadaran masyarakat dengan nilai spiritual Islam dalam pelestarian lingkungan. Berbagai kegiatan dilakukan 
seperti yang tertera diatas, yang menjadikan kawasan sungai code menjadi lebih bersih.

\section{B. Pemahaman Masyarakat atas Program DPPM UII}

Tingkat partisipasi masyarakat sangat baik, dengan hadirnya mereka dalam berbagai acara dari saaat FGD, yang dihadiri oleh tokoh masyarakat, perangkat desa, pengelola masjid, serta tenaga ahli hingga programprogram lain berbasis Eco Spiritual, seperti pendidikan lingkungan bagi anak-anak TPA, kegiatan lomba bersih, kegiatan mural, dsb. Dengan adanya lembaga pengelola yang terus aktif dalam menjalankan misinya didukung oleh Pemerti Code, maka kelangsungan program ini dapat berjalan secara berkelanjutan, tidak hanya pada saat pemberian bantuan program saja.

\section{Kesadaran Masyarakat untuk Mandiri}

Masyarakat Code yang tinggal dengan berhimpitan membut sikap gotong royong menjadi salah satu budaya mereka. Sebelum dan setelah ada program masyarakat memiliki sikap gotong royong demi terwujudnya kawasan Sungai Code yang bersih. Dengan adanya lembaga pengelola yang terus aktif, maka masyarakat tetap dapat menjalankan program tanpa adanya ketergantungan. Kawasan Code bermitra dengan berbagai universitas, pemda dan swasta dalam menjalankan berbagai program, dikarenakan Kawasan Code sangat menarik untuk dijadikan tempat penelitian dan aktifnya lembaga Pemerti Code.

Program ini telah dilaksanakan selama beberapa tahun, dengan mengadakan berbagai kegiatan untuk kebersihan lingkungan berbasis spiritual. Konsistensi lembaga pengelola beserta Pemerti Code yang terus mengkampanyekan kebersihan lingkungan dapat terlihat dengan lebih tertata dan bersihnya kawasan bantaran dan Sungai Code itu sendiri dari sampah. Kawasan pun terlihat lebih menarik dengan adanya berbagai mural sebagai wujud apresiasi seni dan komunikasi terhadap masyarakat.

Kampung code banyak memiliki jaringan dan sudah bermitra dengan berbagai universitas, pemda, maupun swasta. Program DPPM UII, Eco - Spiritual dapat dilepas melihat keberlanjutan program sudah dapat berjalan dengan baik dibawah kelembagaan yang terbentuk.

Tabel 1. Analisis parameter hasil observasi di lapangan

\begin{tabular}{|c|c|c|c|}
\hline \multirow[b]{2}{*}{ DESA MITRA } & \multicolumn{3}{|c|}{ PARAMETER DAN ANALISIS HASIL OBSERVASI } \\
\hline & $\begin{array}{l}\text { Keberhasilan } \\
\text { Program }\end{array}$ & $\begin{array}{l}\text { Pemahaman } \\
\text { Masyarakat atas } \\
\text { Program DPPM UII }\end{array}$ & $\begin{array}{l}\text { Kesadaran } \\
\text { Masyarakat } \\
\text { Mandiri }\end{array}$ \\
\hline $\begin{array}{lr}\text { Industri } & \text { Kreatif } \\
\text { Kerajinan Anyaman } \\
\text { Bambu Desa Brajan, } \\
\text { Desa Sendangagung }\end{array}$ & $\begin{array}{lr}\text { Optimalisasi } & \text { potensi } \\
\text { desa } & \text { dan } \\
\text { pengembangannya }\end{array}$ & $\begin{array}{l}\text { Kesadaran masyarakat } \\
\text { terhadap kebutuhan air } \\
\text { bersih dan nilai } \\
\text { ekonomisnya }\end{array}$ & $\begin{array}{l}\text { Kebutuhan terhadap } \\
\text { pengembangan jaringan } \\
\text { dan pemasaran }\end{array}$ \\
\hline 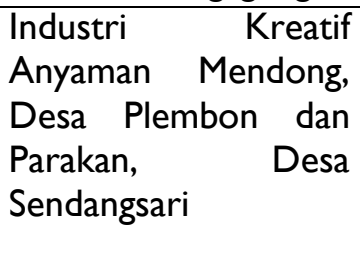 & $\begin{array}{l}\text { Potensi ada yang belum } \\
\text { dimaksimalkan } \\
\text { pengelolaannya, masih } \\
\text { membutuhkan pelatihan } \\
\text { SDM sebagai pelaku } \\
\text { industri }\end{array}$ & $\begin{array}{l}\text { Kebutuhan akan } \\
\text { pendampingan untuk } \\
\text { diversifikasi produk dan } \\
\text { pengelolaan }\end{array}$ & $\begin{array}{lr}\text { Regenerasi } & \text { pelaku } \\
\text { industri } & \text { untuk } \\
\text { keberlanjutan program }\end{array}$ \\
\hline $\begin{array}{lr}\text { UKM } & \text { Pasir Semen } \\
\text { Desa } & \text { Pusmalang, } \\
\text { Desa } & \text { Wukirsari }\end{array}$ & $\begin{array}{lr}\begin{array}{l}\text { Program } \\
\text { karena }\end{array} & \begin{array}{r}\text { berjalan } \\
\text { adanya }\end{array} \\
\text { pendampingan, } & \\
\text { keinginan } & \text { untuk } \\
\text { berkembang } & \text { dan } \\
\text { memanfaatkan } & \text { potensi }\end{array}$ & $\begin{array}{lr}\text { Mendorong } & \text { untuk } \\
\text { memperkuat } & \text { jaringan } \\
\text { pemasaran } & \end{array}$ & $\begin{array}{l}\text { Kebutuhan } \\
\text { pengembangan } \\
\text { kapasitas } \\
\text { meningkatkan } \\
\text { kemandirian }\end{array}$ \\
\hline
\end{tabular}


Prihatmaji, et al

\begin{tabular}{|c|c|c|c|}
\hline & belum terbentuk & & \\
\hline $\begin{array}{lr}\text { Ekonomi } & \text { Kreatif } \\
\text { Berbasis Lingkungan } \\
\text { di Desa Morangan, } \\
\text { Desa Sindumartani }\end{array}$ & $\begin{array}{lr}\text { Optimalisasi } & \text { potensi } \\
\text { desa } & \text { dan } \\
\text { pengembangannya } & \end{array}$ & $\begin{array}{l}\text { Kesadaran masyarakat } \\
\text { terhadap kebutuhan air } \\
\text { bersih dan nilai } \\
\text { ekonomisnya }\end{array}$ & $\begin{array}{l}\text { Kebutuhan terhadap } \\
\text { pengembangan jaringan } \\
\text { dan pemasaran }\end{array}$ \\
\hline $\begin{array}{lr}\text { Ekonomi Kreatif } \\
\text { Berbasis Lingkungan } \\
\text { dan Budaya Sungai } \\
\text { Code, Kampung } \\
\text { Jetisharjo, Kelurahan } \\
\text { Cokrodiningratan }\end{array}$ & $\begin{array}{ll}\begin{array}{l}\text { Pengembangan } \\
\text { program }\end{array} \\
\text { kebutuhan } \\
\text { masyarakat }\end{array}$ & $\begin{array}{l}\text { Kebutuhan masyarakat } \\
\text { yang } \\
\text { meningkat akan air } \\
\text { bersih }\end{array}$ & $\begin{array}{l}\text { Kebutuhan terhadap } \\
\text { pengembangan jaringan } \\
\text { dan pemasaran }\end{array}$ \\
\hline
\end{tabular}

Tampak dalam Tabel 1 tersebut bahwa kebijakan teknis yang dapat dilakukan berkaitan dengan evaluasi 5 desa mitra tersebut dapat diputuskan berdasarkan hasil analisis tersebut. Analisa pembahasan ini didasarkan pada kondisi yang ada dengan rincian pembahasan berdasarkan parameter dan indikator yang ada yakni keberhasilan program, pemahaman masyarakat atas program DPPM UII dan kesadaran masyarakat untuk mandiri.

\section{Peran DPPM UII}

Penyusunan business plan desa mitra binaan yang dilaksanakan oleh DPPM UII di tujuh lokasi, direncanakan selama 4 (empat) tahun sesuai dengan periodisasi kepengurusan DPPM UII. Dasar penyusunan ini juga dengan melihat fungsi dan peran DPPM UII di lingkungan akademik secara internal, yakni sebagai berikut:

DPPM UII memiliki tugas dan fungsi sebagai unit di lingkungan akademik UII, lingkupnya adalah sebagai berikut :

a. Mediator secara institusi yang menghubungkan demand dan supply, problem dan solusi masyarakat dengan UII.

b. Lembaga yang mengkoordinasikan penelitian dan pengabdian masyarakat untuk kepentingan masyarakat.

c. Lembaga yang mengkoordinasikan hasil-hasil penelitian dan pengabdian masyarakat dalam bidang sains dan teknologi, serta sosial dan humaniora.

Penguatan peran DPPM UII secara eksternal diarahkan sebagai pendamping pemerintah, mengoptimalkan swasta dalam mewujudkan program sebagai bagian visi perusahaan dan pemberdayaan masyarakat sebagai pelaku utama dalam pembangunan berkelanjutan. Penguatan peran DPPM UII secara eksternal sebagai fungsi penelitian dan pengabdian masyarakat diarahkan sebagai berikut :

a. Menghadirkan akademisi-akademisi yang ahli di bidang riset dan pengabdian masyarakat yang mampu mendukung pembangunan Kabupaten Sleman khususnya dan DIY pada umumnya

b. Menjadi mitra BUMN di lingkup DIY untuk penguatan kapasitas, advokasi dan edukasi dalam pengembangan perusahaan

c. Menjadi pendamping Pemerintah Daerah dalam melahirkan kebijakan strategis untuk pembangunan wilayah.

\section{Program yang telah Dilaksanakan}

Selain melihat dari peran DPPM UII baik secara internal maupun eksternal, penyusunan business plan tahun 2010-2014 ini didasarkan dengan melihat ragam program kegiatan yang dilaksanakan oleh DPPM UII pada 5 desa mitra, oleh dosen/peneliti serta mahasiswa yang sesuai dengan bidang keilmuwannya. Hal ini diperlukan untuk melihat potensi yang ada dari hasil identifikasi, program lain yang sudah berjalan, rencana pembangunan desa dan kebutuhan masyarakat, sehingga dapat dihasilkan rencana keberlanjutan untuk mengoptimalkan pengembangan desa dalam koridor wilayah desa.

Jenis kegiatan yang dilaksanakan meliputi :
a. Penguatan pengolahan dan pemasaran produk
b. Manajemen pengelolaan industri 
c. Pembentukan kelembangan pengelola industri

d. Penguatan kapasitas kelembagaan pengelola industri

e. Pembangunan showroom industri

f. Penguatan terhadap mutu produk

g. Strategi membangun mitra dan jaringan pemasaran

h. Pengelolaan desa wisata

i. Pengenalan teknologi

j. Pemeliharaan dan penataan lingkungan

Ragam kegiatan yang sudah dilaksanakan masih terfokus pada beberapa sektor, sehingga belum ada skenario besar yang mampu memayungi kebutuhan pembangunan desa baik secara fisik maupun penguatan sumber daya manusia sebagai pelaku pembangunan.

\section{Rencana Keberlanjutan Program}

Pendampingan desa mitra agar berjalan secara efektif dan sesuai dengan tujuannya, maka sebaiknya pendampingan hanya dilakukan pada beberapa desa saja. Terlalu banyak desa mitra dalam sekali waktuakan mengakibatkan proses pendampingan tidak fokus, dan pada akhirnya tidak dapat menghasilkan sesuatu yang berkelanjutan. Dari survey yang telah dilakukan pada desadesa tersebut berdasarkan pada parameter dan indikator diatas, maka pendampinganDPPM UII terhadap desa dapat dikerucutkan dan difokuskan pada tiga desa, dengan masing masing arah rencana keberlanjutan program, yaitu:

\section{Desa Brajan, Desa Sendangagung}

Program pendampingan DPPM UII di Desa Brajan telah berjalan selama 8 tahun. Hal tersebut merupakan waktu yang sangat lama. Sudah saatnya melakukan pengembangan bukan hanya pada level desa, tetapi pada level desa, yaitu Desa Sendangagung. Rencana tindak lanjut yang diarahkan adalah sebagai berikut:

a. Evaluasi produk perencanaan dan pengembangan kawasan Sendangagung 2035 (2015) b. Pendampingan terhadap rencana kerja jangka pendek (pengembangan kawasan 2035 ) ( 2016-2017)

c. Penguatan terhadap diversifikasi bahan baku produksi ( 2016 )

d. Perencanaan terhadap pengelolaan industri dalam skala desa ( 2016 )

e. Penguatan kapasitas untuk kelompok industri terhadap teknologi tepat guna (2018)

2. Desa Pusmalang, Desa Wukirsari

Bahan baku pasir yang melimpah tidak dapat diperkirakan dalam jangka waktu lama untuk ketersediaannya, dengan berbagai potensi yang ada dan keinginan masyarakatnya untuk berwirausaha sebagai landasan pendampingan di Desa Pusmalang, Desa Wukirsari dapat dilanjutkan dengan arah pengembangan, sebagai berikut:

a. Evaluasi produk perencanaan dan pengembangan kawasan desa Wukirsari 2035 (2015)

b. Pendampingan terhadap rencana kerja jangka pendek (pengembangan kawasan 2035) (2016-2017)

c. Penguatan kapasitas dan kelembagaan desa (2016)

d. Revitalisasi aktivitas perikanan dan pertanian sebagai mata pencahariaan utama (2017)

e. Penguatan kapasitas untuk kelompok industri terhadap teknologi tepat guna (2018)

3. Desa Morangan, Desa Sindumartani

Melihat keberhasilan program DPPM UII sebelumnya, dan masyarakat yang kondusif, maka pendampingan DPPM UII di Desa Sindumartani dilanjutkan dengan arah pengembangan, sebagai berikut:

a. Evaluasi produk perencanaan dan pengembangan kawasan Sindumartani 2035 (2015)

- Sosialisasi masyarakat

- FGD

- Konsultasi dengan pemerntah daerah

- Kesepakatan bersama 
b. Pendampingan terhadap rencana jangka pendek berupa pengembangan kawasan 2035 (2016-2017)

c. Penguatan mitigasi bencana (2015)

d. Kerjasama swasta untuk supplier air bersih dan air minum (2016-2017)

e. Optimalisasi potensi perikanan dengan pengembangan kawasan Minapolitan (2018)

\section{KESIMPULAN}

Pendampingan DPPM UII terhadap desa binaan yang telah dilakukan selama beberapa tahun terakhir banyak memberikan dampak positif bagi perkembangan desa. Bekerjasama dengan pihak lain , DPPM UII mampu memberikan kontribusi yang nyata. Menggunakan pendekatan ke masyarakat dan melibatkan peran masyarakat di dalam setiap proses dilakukan DPPM UII agar mendorong masyarakat turut serta aktif dalam pembangunan desanya, sehingga program dan hasil dapat sesuai dengan apa yang di butuhkan oleh masyarakat itu sendiri.

Keinginan DPPM UII agar program pendampingan terhadap desa mitranya berjalan secara maksimal, dan dapat mewujudkan desa mandiri yang berkelanjutan, maka dilakukan kegitan survey pasca pelaksanaan program untuk dapat mengetahui seberapa besar dampak pendampingan yang telah dilakukan DPPM UII terhadap perkembangan desa, dan untuk mengetahui bagaimana kelanjutan programprogram tersebut, sebagai bahan acuan rencana kegiatan selanjutnya yang akan dilakukan oleh DPPM UII. Hasil kegiatan survey tersebut juga akan menentukan sikap apa yang akan diambil oleh DPPM UII terhadap desa-desa tersebut, yaitu: a) Melanjutkan program pendampingan, b) Menunda program pendampingan, c) Tidak melanjutkan program pendampingan. Hal ini dilakukan agar kegiatan DPPM UII lebih fokus dan terarah, sehingga dapat mewujudkan desa yang berkelanjutan.

Berdasarkan analisis yang telah dilakukan, DPPM UII telah berusaha untuk mengoptimalkan potensi di masing masing desa. Faktor lain yang mempengaruhi keberhasilan program DPPM UII ditentukan oleh adanya embrio masyarakat yang memiliki kebutuhan untuk mengembangkan desanya agar perekonomian meningkat. Tanpa adanya keinginan dari masyarakat berdampak pada ketidakberlanjutan program. Arah kedepannya masyarakat masih membutuhkan pendampingan untuk kemandirian. Regenerasi dan pengembangan kapasitas keberlanjutan program serta pengembangan jaringan sangat diperlukan agar program dapat berjalan secara berkelanjutan.

\section{UCAPAN TERIMAKASIH}

Ucapan terimakasih disampaikan kepada Direktorat Penelitian dan Pengabdian Masyarakat Universitas Islam Indonesia (DPPM UII) yang telah membiayai penelitian ini hingga purna dilaksanakan. Ucapan terimakasih juga disampaikan kepada Housing Resource Center Yogyakarta yang telah membantu dalam pelaksanaan penelitian ini. Semoga hasil penelitian ini bermanfaat khususnya bagi pengembangan desa mitra DPPM UII dan umumnya bagi semua masyarakat akademis dan masyarakat umum.

\section{DAFTAR PUSTAKA}

Maksudin, 200I, Strategi Pengembangan Potensi dan Program Desa Binaan/Mitra Kerja IAIN Sunan Kalijaga Yogyakarta, Jurnal Aplikasia, Vol.2 No.2 Edisi Desember 200I, P2M IAIN Sunan Kalijaga Yogyakarta.

Margono Slamet, 1993,"Arti dan Metode Pengabdian pada Masyarakat dan bentukbentuk pelaksanaannya oleh Perguruan Tinggi", dalam Agussalim Sitompul (ed), Metodologi Pengabdian pada Masyarakat, Yogyakarta: P2M IAIN Sunan Kalijaga Yogyakarta.

M. Iqbal Hasan. 200I. Pokok-pokok Materi Statistik I (Statistik Deskriptif), Bumi Aksara. Jakarta.

Nawawi, H. 1995. Metode Penelitian Bidang Sosial. Yogyakarta : Gajah Mada University Press.

Netting F.E. (ed), 1993. Social Work Macro Practice, London, Longman Group Ltd.

Pangestu Subagyo, 2003. Statistik Deskriptif, Yogyakarta : BP FE UGM. 
Singarimbun, Masri.1995. Metode Penelititan Survei. LP3S, Jakarta

Sukidjo, 2000, Tujuan dan khalayak sasaran PPM, Jurnal Aplikasia, Vol.I No.I edisi Desember 2000, P2M IAIN Sunan Kalijaga Yogyakarta.

Syafri Mangkuprawira. 1993. "Metode Analisis dan Pemecahan Masalah Masyarakat", dalam Agus Salim Sitompul. Metodologi Pengabdian Pada Masyarakat. Yogyakarta: P3M IAIN Sunan Kalijaga Yogyakarta. p. 14 